$$
\begin{gathered}
\text { 급성심근경색증 및 뇌경색증과 연관된 전이성 췌장암 } 1 \text { 예 } \\
\text { 경희의료원 순환기내과, }{ }^{1} \text { 광주보훈병원 순환기내과, }{ }^{2} \text { 여수전남병원 내과 } \\
\text { 서상운 }{ }^{2} \cdot \text { 김 }{ }^{*}{ }^{*} \cdot \text { 황선호 }^{1} \cdot \text { 강원유 }^{1} \cdot \text { 구 } \text { 철 }^{2} \cdot{\text { 김 } \text { 완 }^{1}}
\end{gathered}
$$

\title{
A Case of Acute Myocardial Infarction and Cerebral Infarction Associated with Metastatic Pancreatic Carcinoma
}

\author{
Sang Woon $\mathrm{Seo}^{2}$, Weon $\mathrm{Kim}^{*}$, Sun $\mathrm{Ho} \mathrm{Hwang}^{1}$, Won Yu Kang${ }^{1}$, Chul $\mathrm{Gu}^{2}$ and Wan $\mathrm{Kim}^{1}$ \\ Department of Cardiovascular Medicine, KyungHee University Medical Center, Seoul, ${ }^{1}$ Cardiovascular Center, \\ Gwangju Veterance Hospital, Gwangju, Internal Medicine, Yeosu Chonnam Hospital, Yeosu, Korea
}

\begin{abstract}
Acute myocardial infarction without angiographic evidence of arteriosclerosis is uncommon. We report the case of a 63-year-old female patient with acute myocardial infarction. Coronary angiography showed thrombotic total occlusion in the mid left anterior descending artery and thrombotic critical stenosis in the proximal left circumflex artery. Despite multiple balloon angioplasty and aspiration of thrombi, distal flow in the left anterior descending and left circumflex arteries only improved slightly, because abundant thrombi remained. No residual stenosis was observed on angiography. However, computed tomography of the abdomen showed a 5-cm low-attenuated mass with a peripheral enhanced rim in the pancreas and a maximal 7-cm multiple ill-defined peripheral enhanced low-attenuated mass in the liver. Unfortunately, the patient experienced multiple embolic cerebral infarctions 7 days later. The patient had no relevant cardiovascular disease risk factors, signs of heart failure, or arrhythmia. We believe that the pathogenetic mechanism responsible for myocardial infarction in this patient was in situ thrombosis.
\end{abstract}

Key Words: Acute myocardial infarction; Cancer; Thrombosis

\section{서 론}

혈전색전증은 암환자에서 흔한 합병증이자 주요 사망원인 이다. 암의 특징적인 과응고상태는 혈액응고, 혈소판-혈관벽 의 상호작용, 섬유소용해, 염증성 cytokine 생성 등과 깊은 관련이 있다. 즉, 암환자에서 혈전증 발생은 종양의 성장을

게재결정: 2009년 5월 11일

*교신저자: 김 원, 130-701 경희의료원 순환기내과, Phone: 02-958-8176,

FAX: 02-958-8160, E-mail: mylovekw@hanmail.net
억제하려는 숙주의 과잉 반응의 결과라고 할 수 있다. ${ }^{1}$ 혈전 색전증은 정맥계와 동맥계 모두에 영향을 미친다. 동맥성 임 상양상은 국소적 동맥 폐색, 비세균성 혈전성 심내막염, 파 종성 혈관내 응고증, 혈전성 저혈소판 자반증 등이다. 췌장, 폐와 위장관의 점액암종은 전통적으로 혈전색전증과 연관되 어 있다. ${ }^{2}$

혈전색전증 등에 의한 급성심근경색증의 유발 보고는 드 물게 있지만, 급성심근경색증과 암과의 관련성에 대해 명확 히 정리된 바는 없다. 문헌 고찰 결과 아직까지 전이성 췌장 
암에 의한 관상동맥 혈전증으로 급성심근경색증을 일으킨 예는 국내에 보고된 바가 없었다. 이에 저자들은 췌장암으로 인한 혈전증에 의해서 급성심근경색증과 뇌경색증이 발생된 증례를 경험하였기에 문헌고찰과 함께 보고하는 바이다.

\section{증 례}

환 자: 박 $\bigcirc$, 여자 63세

주 소: 내원 1 시간 전부터 시작된 흥통

현 병력: 내원 1 시간 전 집안 일을 하던 중 하흥부 중심부 에 통증이 발생하여 응급실로 내원하였다. 통증은 짓누르는 양상이었으며, 식은 땀과 호흡곤란을 동반하고, 양팔로 퍼져 나가는 양상이었다. 환자는 내원 15 일 전부터 우상복부 통 증 및 식욕부진, 오심이 있었지만, 구토, 발열, 오한 등은 없 었다.

과거력: 흡연 및 음주력은 없었으며, 특정약물은 복용하지 않았다. 당뇨, 고혈압 및 수술병력은 없었다.

가족력 및 개인력: 특이사항은 없었다.

이학적 소견: 응급실 내원 당시 혈압은 $110 / 70 \mathrm{mmHg}$, 심박수 88 회/분, 호흡수 22 회/분, 체온은 $36.5^{\circ} \mathrm{C}$ 였다. 환자 는 급성 병색을 보였으나 의식은 명료하였다. 결막은 창백했 고, 공막의 황달 소견은 없었다. 흥부 청진 상 특이소견은 없었으며, 복부 진찰상 간 및 비장종대는 없었고, 잡음은 청 진되지 않았으나, 경미한 상복부 및 우상복부 압통이 동반되 어 있었고 위장관 운동은 약간 감소되어 있었다.

진단의학검사: 입원 당시 시행한 혈액학적 검사에서 혈색 소는 $10.0 \mathrm{~g} / \mathrm{dl}$, 백혈구 $18,500 / \mathrm{mm}^{3}$, 혈소판 $140,000 / \mathrm{mm}^{3}$ 이었다. 생화학적 검사에서 혈당 $180 \mathrm{mg} / \mathrm{dl}$, 총단백 6.6 $\mathrm{g} / \mathrm{dl}$, 알부민 $4.0 \mathrm{~g} / \mathrm{dl}$, 총빌리루빈 $1.13 \mathrm{mg} / \mathrm{dl}$, 직접 빌리루 빈 $0.33 \mathrm{mg} / \mathrm{dl}$, AST $329 \mathrm{U} / \mathrm{L}$, ALT $83 \mathrm{U} / \mathrm{L}$, alkaline phosphatase 260 U/L, $\gamma$-GTP 184 U/L, LDH 1949 U/L, BUN $7.1 \mathrm{mg} / \mathrm{dl}, \mathrm{Cr} 0.7 \mathrm{mg} / \mathrm{dl}$ 이었다. 혈액응고검사에서 PT $18.7 \mathrm{sec}$ (INR 1.57), aPTT $27.6 \mathrm{sec}$ 이었고, creatine kinase-MB $3.7 \mathrm{ng} / \mathrm{ml}$, troponin I $0.13 \mathrm{ng} / \mathrm{ml}$, troponin T $<0.01 \mathrm{ng} / \mathrm{ml}$ 이었다. 혈청 전해질 검사와 소변 검사는 정상 범위였다. 직장수지 검사와 대변 잠혈 반응 검사에서 모두 음성을 보였다.

심전도: $\mathrm{V} 3 \sim \mathrm{V} 6$ 에서 $2 \mathrm{~mm}$ 이상의 ST분절 상승이 관찰 되었다(Fig. 1).

심초음파: 좌심실 구혈율 39 42\%의 중등도의 좌심실

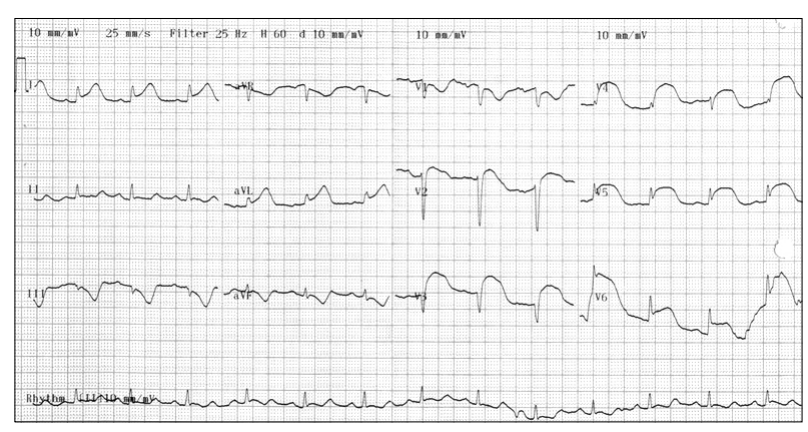

Fig. 1. Electrocardiography showed extensive ST elevation in V2 to V6 and I, aVL and marked T inversion in III, aVF compatible with acute anterolateral myocardial infarction.

수축기능 감소와 전벽, 전중격벽, 후측벽 등의 무수축 운동 장애 및 좌심실 첨부의 동맥류가 관찰되었다. 컬러도플러 상 비정상 혈류 및 심낭삼출액은 관찰되지 않았다.

임상경과 I - 심혈관조영술 및 관상동맥중재술: 환자는 응 급실에서 급성심근경색증 진단 하에 응급 관동맥조영술을 시행하였다. 내원 직후 enoxaparin $30 \mathrm{mg}$ 정주 후 1 $\mathrm{mg} / \mathrm{kg}$ 피하 주사하였고, aspirin $300 \mathrm{mg}$, clopidogrel 600 $\mathrm{mg}$ 을 복용하였다. 확진을 위해 시행한 관동맥조영술에서 중 간부 좌전하행지의 혈전성 완전 폐쇄 및 좌회선지 관동맥과 둔각변연 분지의 분기점에 큰 혈전 소견이 관찰되었다(Fig. $2 \mathrm{~A}, \mathrm{~B})$. 고위험군 관동맥중재술로 판단되어 $\mathrm{abciximab}$ $0.25 \mathrm{mg} / \mathrm{kg}$ 를 관동맥 내로 투여하고, $0.125 \mathrm{mg} / \mathrm{kg}$ 를 12시 간 동안 정주하기로 하였다. 먼저 좌전하행지 완전 폐쇄 병 변에 대해 중재술을 시행하기로 하고, $\mathrm{EBU} 3.5$ 관동맥 유 도도자를 위치시키고 Run-through wire (Terumo ${ }^{\circledR}$, Japan) 를 성공적으로 통과시킨 후 $2.5 * 20 \mathrm{~mm}$ 의 splinter 풍선도 자(Medtronics $\left.{ }^{\circledR}, \mathrm{USA}\right)$ 를 이용하여 10 기압으로 풍선확장 술을 시행하였다. 그러나, 수차례의 풍선확장술에도 불구하 고 관상동맥 혈류는 회복되지 않았다. 그래서, thrombuster catheter (Medtronics ${ }^{\circledR}$, USA) 를 이용하여 수차례 혈전을 흡입하였고(Fig. 2C), 이후 원위부 좌전하행지에 대해 풍선 확장술을 추가로 시행한 후에야 약간의 혈류 회복이 관찰되 었다. 소량의 혈전이 흡입되었으나(Fig. 2F), TIMI III 혈류 는 회복되지 않았다(Fig. 2D). 좌회선지 혈전에 대해서도 수차례 혈전흡입술 및 풍선확장술을 시행하였으나 완벽히 성공하지는 못하고 좌회선지 및 둔각변연 분지 최하부로 혈 전이 이동하여 폐쇄소견을 보였다(Fig. 2E).

환자는 관동맥중재술을 시행한 후 중환자실로 전실되었 다. 시술 후 환자의 흥통은 완화되었으며, 생체징후도 안정 화되었다. 그러나, 환자에게 동맥경화의 위험인자가 없었고, 

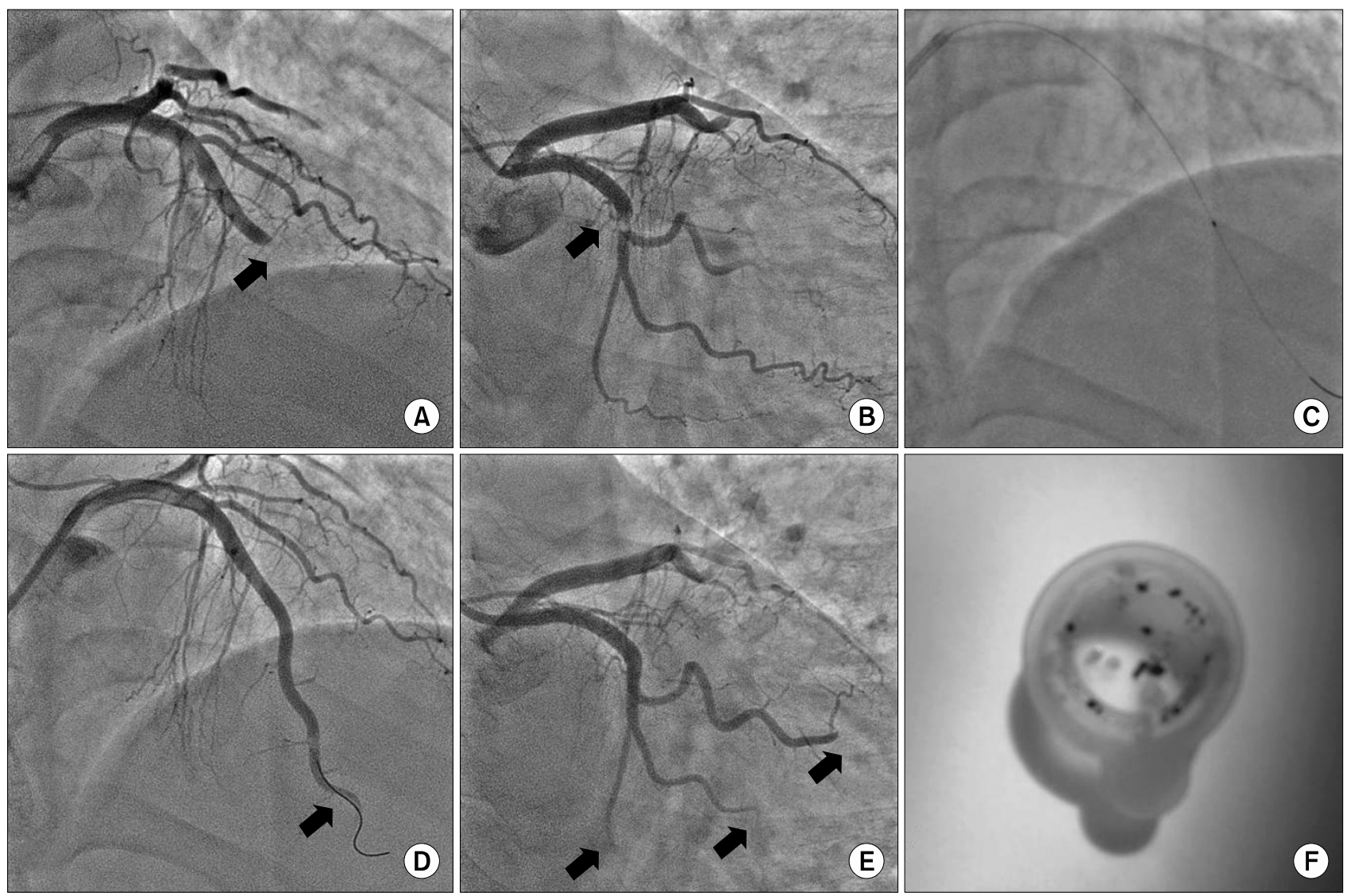

Fig. 2. Coronary angiogram (CAG) via right transradial approach showed thrombotic total occlusion in midddle left anterior descending artery (LAD) with poor collateral circulation (A) and large thrombotic burden in proximal left circumflex artery (LCX) birfucation site (B). After successful wiring, POBA (plain old balloon angioplasty) was performed using $2.0 \mathrm{~mm}$ and $3.0 \mathrm{~mm}$ sized balloon catheter for LAD and LCX several times. And, aspiration of thrombi using Thrombuster suction device was performed many times (C). Final CAG showed markedly improved flow of LAD and LCX, but distal embolic occlusions in LAD, LCX, and OM (Obtuse marginal) branch were observed (D,E). Small amount thrombi were aspirated by suction catheter (F).

관동맥에서도 풍부한 혈전에 비해 협착소견이 저명하지 않 아 다른 원인에 의한 혈전색전성 심근경색증 의심 하에 추 가적인 검사를 시행하였다.

임상경과 II - 복부 전산화단층촬영: 다음날 시행한 복부 초음파에서 췌장 체부와 위 체부의 후벽에 걸쳐서 불균일한 에코음영을 보이는 $5.8 \times 3.4 \mathrm{~cm}$ 크기의 종양성 음영 및 주 변 후복막강 림프절의 확장이 관찰되었다. 간의 양쪽 엽에 산발한 다양한 크기의 에코음영이 관찰되었다. 직후 시행한 복부 전산화단층촬영 상 췌장 체부와 미부에 약 $5.5 \mathrm{~cm}$ 크 기의 주변부가 조영 증강되는 저음영의 종양이 확인되었으 며, 이 종양은 위 체부와 소만부를 침범하는 것이 의심되었 다. 원위부 췌장관의 확장도 관찰되었다(Fig. $3 \mathrm{~A})$. 간에 최 대 $7 \mathrm{~cm}$ 크기의 다수의 주변부가 조영 증강되는 저음영의 전이성 종양이 관찰되었다(Fig. $3 \mathrm{~B})$. 대장에 비정상적으로 조영 증강되는 종양은 관찰되지 않았다.
임상경과 II - 자기공명영상촬영: 환자는 췌장암과 다발성 간전이 및 급성심근경색증으로 보존적 치료를 시행하던 중 타 병원으로 전원되었다. 환자는 간 조직검사(liver biopsy)를 시행하기 위해 aspirin, clopidogrel, enoxaparin을 중단하고 경과관찰하던 중, 급성심근경색증 발생 6 일째 다발성의 색전 성 뇌경색증이 발생하였다(Fig. $4 \mathrm{~A}, \mathrm{~B}$ ). 환자는 aspirin, heparin 등으로 치료를 받았으나, 후유증으로 감각실어증 등 이 발생하였다. 이후 환자는 적극적인 치료를 시행하지 못하 고 보존적 치료를 지속해 오던 중 내원 35 일 만에 사망하였다.

\section{고 찰}

관상동맥의 혈류 결손과 급성심근경색증 발생의 주요한 원인은 관상동맥의 동맥경화증이며 동맥경화반의 파열에 의 

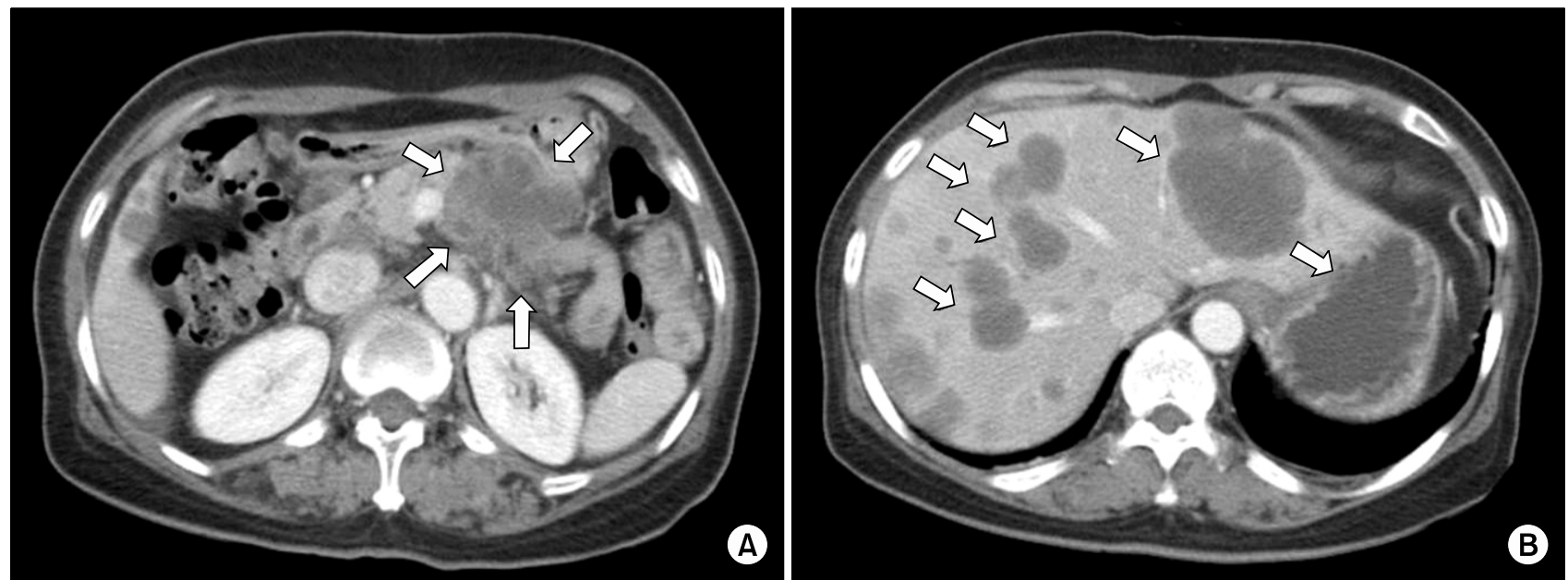

Fig. 3. Computed Tomography (CT) scan of abdomen showed enlarged body and tail of pancreas with $5 \times 5 \mathrm{~cm}$ sized heterogenous soft tissue mass with multiple lymph node enlargement (A) and multiple metastatic mass (maximum $7 \mathrm{~cm}$ sized) in liver (B).
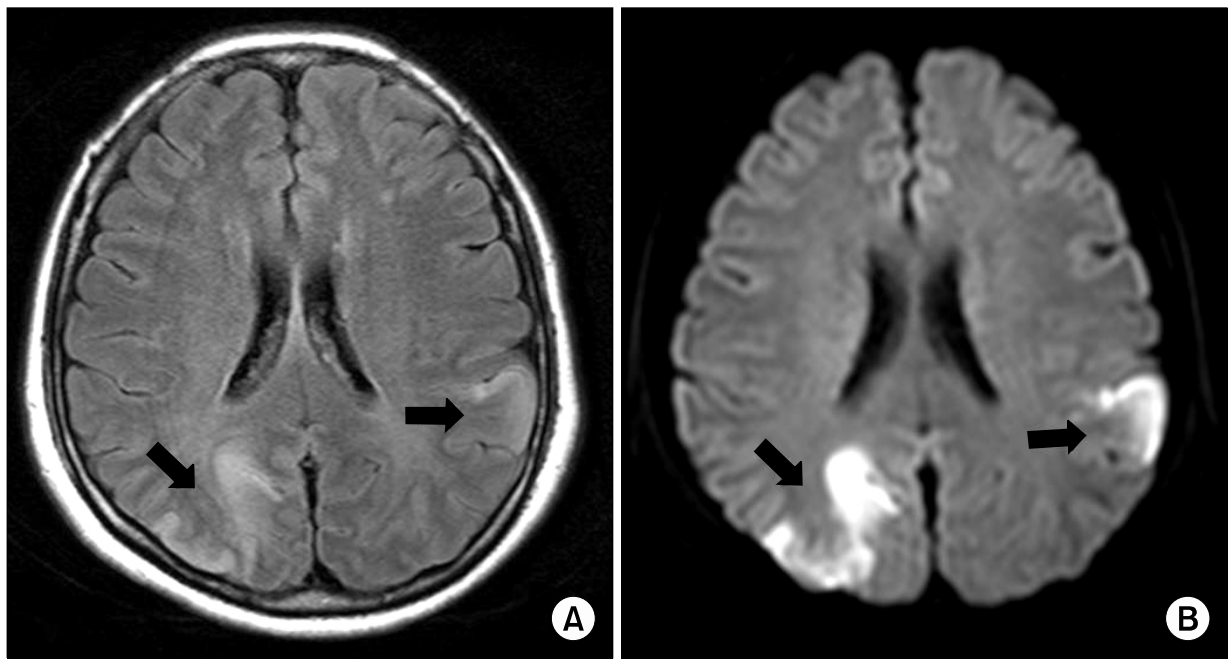

Fig. 4. Axial T2WI (T2-weighted imaging) MR (Magetic Resonance) image (Fast spin echo;FLAIR=Fast fluid-attenuated inversion-recovery) showed Increased signal intensity in left parietal and right occipital lobe (A), and Axial DWI (Diffusion-weighted) MR showed diffusion restriction in the same areas $(B)$.

한 혈전의 형성과 관련되어 있다. 그 외, 다른 원인으로 비동맥경화성 관상동맥질환, 관상동맥의 혈전색전증, 관상 동맥의 선천성 기형, 혈액 과응고증 등의 혈액학적 질환, 암 성 병변 등이 있다. 원발성 심장종양 또는 이차적으로 전이 된 종양의 외부압박에 의한 관상동맥 혈류의 결손은 상대적 으로 드문 경우인데 전체 원인 중 $0.1 \%$ 미만으로 알려져 있 다. 심장의 종양 침범에 의한 효과는 (1) 원발성 종양에 의 한 심전도 변화 (2) 종양에 의한 관상동맥 혈류의 결손: 혈 관침범 없이 외부에서 관상동맥 압착, 종양의 혈관침범에 의 한 폐쇄, 대동맥판막의 종양으로 관상동맥 입구의 폐쇄, 종 양에 의한 색전증 (3) 심장구조 변화없이 급성심근경색증에 특징적인 심전도 변화 등이 있다. ${ }^{3}$

심방의 점액종이나 섬유탄력종 등에 의한 관상동맥 색전
으로 급성심근경색증이 발생한 증례는 간혹 볼 수 있다. ${ }^{4}$ 그 러나, 심장 외부의 고형암과 관련된 증례는 매우 드물게 보 고되고 있다. Selvanayagam 등 ${ }^{5}$ 은 직장암에서 유도된 관상 동맥 혈전증에 의해서 급성심근경색증이 유발된 증례를 보 고한 바 있다. Brazdzionyte 등 ${ }^{3}$ 은 전신에 전이된 폐암을 가 진 67세 남성에서 종양이 직접적으로 흉막과 심장막을 뜷고 좌심실 기저부 쪽으로 자라서 죄회선지 분지의 동맥벽을 침 범하여 내강을 완전히 막아서 급성심근경색증을 유발한 증 례를 보고한 바 있다.

특히 췌장암과 관련된 증례를 보면, Robinson 등은 심장 에 전이된 췌장암이 급성심근경색증을 유발했던 증례를 보 고한 바 있다. 급성심근경색증에 이은 심인성 쇼크로 사망한 환자의 사후 부검에서 폐, 간, 우측 신장과 좌측 부신에 전 
이가 되어 있는 췌장암을 보였고, 심근의 전측벽에 직경 2 $\mathrm{cm}$ 의 전이병소를 갖고 있었다. 거시적으로는 전이병소가 주 요관상동맥을 침범하지 않았으나, 조직학적 검사상 중간 크 기의 동맥이 내강은 침범되지 않은 채 전이종양에 의해 둘 러싸여 있었고, 인접한 신경다발 역시 종양으로 둘러 싸여 있었으며, 인접한 정맥은 악성세포로 완전히 막혀 있었다. 이 증례에서는 관상동맥에 경한 정도의 동맥경화만이 관찰 되었으나, 종양이 전이된 위치는 심전도상의 변화와 해부학 적으로 일치했고, 직접적인 종양의 침범 또는 종양의 색전에 의한 관상동맥 폐쇄가 없었기 때문에 이러한 변화는 종양에 의한 이차적인 것임을 의미했다. ${ }^{6}$ 본 증례에서는 아쉽게도 부검을 시행하지 않아 종양에 의한 직접 침범 여부는 확인 할 수 없었다. 그 외에도, 전이된 췌장 선암종에 의한 비세 균성 혈전성 심내막염에 의해 2차적으로 뇌와 심장에 혈전 성 경색이 발생한 증례를 보고한 바 있다. ${ }^{7}$ 본 증례의 환자 에서는 심장 판막에 유의한 병변은 보이지 않아 판막질환에 의한 전이성 색전성 심근경색증은 배제할 수 있었다. 그러나 본 증례의 경우 비록 부검을 시행하지 않아 조직학적으로 확진할 수는 없었지만 전이성 종양에 의한 관상동맥 혈전색 전증 또는 in situ 혈전증이 심근경색증의 원인이었을 가능 성이 높다고 말할 수 있겠다. 즉, 동시다발적인 관상동맥내 혈전 발생, 과거력 및 가족력의 부재, 죽상동맥경화증의 위 험인자 부재 및 관상동맥 조영술상 저명한 동맥경화성 병변 의 부재 등을 그 근거로 들 수 있다.

혈전색전증은 악성종양의 잘 알려진 합병증이다. 임상양상 은 원발성 고형암의 성장에 전형적으로 연관된 정맥성 혈전 색전증, 혈액종양과 광범위한 전이암 환자에서 흔히 관찰할 수 있는 파종성 혈관내 응고증 등이다. 또, 종양성장과 혈액 응고 항진 사이에 밀접한 연관이 있음이 알려져 왔다. 암 환 자에서 지혈장애 기전은 (1) 응고작용, (2) 섬유소용해의 활 성화, (3) 혈관내피세포의 혼란, (4) 순환 단핵구와 혈소판의 표면에 응고를 항진시키는 세포학적 기전의 활성화, 그리고
(5) 종양-특이적 응고-증진 기전 등이 관련되어 있다. ${ }^{1}$ 이것 은 스텐트를 시술받은 환자의 경우 스텐트 혈전증이 암환자 에서 보다 많이 발생하였다는 결과에서도 확인할 수 있다. ${ }^{8}$

암과 동반된 급성심근경색증 환자의 예후는 명확하지 않 지만, 다른 증례 및 본 증례의 환자에서 보듯이 현격히 진행 되거나 매우 심하게 전이된 암 병변과 관련된 경우가 많기 때문에 생존율 및 기간 등은 매우 좋지 않은 것으로 생각된 다. 특히, 과응고성이 항진된 경우 항혈소판제 또는 항응고 제의 조기 중단이 대뇌동맥이나 신동맥과 같은 주요 혈관에 혈전색전증을 초래하여 본 증례에서처럼 치명적인 합병증을 초래할 수 있으므로 보존적 치료라 하더라도 신중하고 엄격 하게 이루어져야 될 것으로 생각된다.

\section{References}

1. Rickles FR, Falanga A. Molecular Basis for the Relationship Between thrombosis and Cancer. Thromb Res 2001;102:215-24.

2. Brenner B. Arterial thrombotic syndromes in cancer patients. Haemostasis 2001;31(Suppl 1):43-4.

3. Brazdzinomyte J, Mickevicine A, Gailys R, Unikas R, Andriulis M, Macas A. Presentation of rare clinical case of myocardical infarction, induced by neoplasmal obturation of coronary artery. Medicana 2002; 38:631-6.

4. Braun S, Schrotter H, Reynen K. Schwencke C, Strasser RH. Myocardial infarction as complication of lt atrial myxoma. Int $J$ Cardiol 2002;101:115-21.

5. Selvanayagam JB, Iler MA, McRitchie RJ. Coronary thrombosis due to malignancy-induced thrombophilia. Inter Med $J$ 2002;32:268-70.

6. Robinson BW, Lewis RR. Myocardial metastasis from carcinoma of pancreas presenting as acute myocardial infarction. $J$ R Soc Med 1982; 75:560-2.

7. Chen L, Li Y, Gebre W, Lin JH. Myocardial and cerebral infartion due to nobacterial thrombotic endocarditis as an initial presentation of pancreatic adenocarcinoma. Arch Pathol Lab Med 2004;128:1307-8.

8. Gross CM, Posch MG, Geier C, Olthoff H, Krämer J, Dechend R, et al. Subacute coronary stent thrombosis in cancer patient. J Am Coll Cardiol 2008;51:1232-3. 